\title{
Sioux Indians Harassed the Early Iowa Settlers
}

\author{
By Harvey Ingham
}

Fort Dodge was established as the frontier outpost of northern Iowa in 1850, just four years after Fort Des Moines was abandoned. Fort Des Moines was located in 1843 and occupied by troops until 1846, the years during which the Sacs and Foxes were removed from the state to Kansas. Between the occupancy of the two forts the Sioux came conspicuously into notice, driving out every white man who attempted to push into their territory, and trying to stem the tide of immigration to the northwest.

The event which more than any other had to do with the establishment of a new fort was old Sidominadotah's attack upon Marsh, the surveyor, in 1848. Sidominadotah is one of the conspicuous figures in our pioneer history. He was a brother of Inkpadutah, and leader of a band of Wahpecoute outlaws. He was commonly called Chief Two Fingers, having lost the remainder of his right hand in battle.

Major Williams knew him well and left an accurate description of him: "Sidominadotah was a man about 5 feet 10 in height, stout and well formed, very active, had a piercing eye, broad face and high cheek bones." The major adds an item to the description which certainly entitles Sidominadotah to be called the man with the iron jaw, "both rows of teeth were double all around in both jaws, and united, forming solid rows in both upper and lower jaws." A dentist could have paid off all of the old scores of the white race in one sitting. When killed he was 45 or 50 years old. He evidently was the leader of all the bands of the northern Iowa' Sioux at that time, or at least held a prominent place among the leaders, for nearly all the attacks upon the whites who began to 
invade the territory. north and west of Des Moines were led by him.

Marsh was engaged in running the United States survey and had come from Dubuque. $\mathrm{He}$ was working north of the forks of the Des Moines river within a few miles of Fort Dodge, on the west side, when Sidominadotah told him to "puckachee," which in Shakespearean English meant to go, and stand not on the order of his going. But Marsh was not alarmed and proceeded with the survey. At that Sidominadotah broke all his instruments, robbed him and his party, and smashed the wagons. Marsh was then glad to retire, although it is recorded that Mrs. Marsh favored fight-the only one of the entire party with any nerve.

Marsh made a report to the government which, taken with reports of other outrages, caused the order to bring troops into the northwest. It was in the same year of 1848 that Sidominadotah drove Lott out of Webster county and also made a raid on the Merrick families at the Boone forks.

\section{New Fort Located}

Brigadier General Mason was ordered in 1849 to locate the new fort as nearly as possible at the northwest corner of the neutral ground. He chose the site where the city of Fort Dodge now stands, and named the new post Fort Clarke. In 1851 General Winfield Scott changed the name to Fort Dodge in honor of General Henry Dodge, Company $\mathrm{E}$ of the Sixth infantry, U.S.A., and came from Fort Snelling to occupy it. With the company Major William Williams came as sutler.

When the pioneer history of northwestern Iowa is written, Major Williams will be the central figure. Every early settler recalls him. He was part of all that happened in the early years. The first store in Algona was established by him and his son, James B. Williams, H. F. Watson-coming later from Fort Dodge to take charge of it. When after three years 
and a half Fort Dodge was abandoned and the troops were ordered north to build Fort Ridgely, he remained, and buying the ground and buildings of the dismantled fortifications, founded the city which perpetuates its name. Major Williams was associated intimately with all the stirring events along the entire frontier, and the only accurate record that remains of many of them is to be found in the pages of his beautifully written manuscript and in the columns of the pioneer newspapers, for which he liberally contributed. He died in 1874.

During the years of occupancy of the fort, Major Williams became acquainted with the various Sioux bands and their leaders. He has left very interesting descriptions of the latter. His estimate of the character of the outfit tallies with that before given of the Wahpecoute: "The Sioux Indians," he says, "who inhabited this district of country were the most desperate characters, made up of renegades from all the bands. They were generally very active, stout Indians, great horsemen. The majority of them were well armed with guns. They always had in their possession horses and mules with white men's brands. They generally encamped on high ground where they couldn't be easily surprised, and when any number of them were together, they encamped in a circle. They were very expert hunters. Their famous leaders, Sidominadotah and Inkpadutah, were very stout, active men, also Titonka and Umpashotah, indeed all of them."

Of Inkpadutah, who led in the Spirit Lake massacre, and who was present in person at the raid on $\mathrm{Mr}$. Call and the settlers south of Algona in 1855, he says: Inkpadutah is about 55 years old, about 5 feet 11 in height, stoutly built, broad shoulders, large head and broad face, high cheek bones, sunken and very black sparkling eyes, big mouth, light copper color, and pock marked in the face."

Umpashotah is of scarcely less interest, as he is the 
Indian who visited with $\mathrm{W}$. H. Ingham three days on the upper Des Moines, when each one was figuring on who was in charge of the expedition, and his name also is associated with the legend of Spirit Lake. Of him Major Williams records:

"Umpashotah, or Umpaga, (Smoky Day) is a very good looking Indian, about 5 feet 10 in height, complexion light yellow, a good forehead, high cheek bones, large dark eyes, aquiline nose and well formed mouth. He has a fine set of teeth, which he shows to good advantage, has an exceedingly cunning expression of the eyes, professes to be a doctor, age about 45 to 50 , and very fond of trading."

Another chief of the Sioux outlaws was Titonka. Of him the major says: "Titonka, Big Buffalo, is over 6 feet high, very well made and very active. His walk is very erect and elastic, long face, aquiline nose, very dark complexion, eye sparkling when aroused, looks very demure. when not excited, wears his hair long, cheek bones painted. When excited, he is a hard looking customer."

These chiefs belonged to the outlaw Sioux. Ish-ta-habah, or Young Sleepy. Eyes, was connected by marriage only, but had brought a band from the Little Rock Sioux and was living along the Des Moines with them. Ish-ta-ha-bah was 50 years old, with pleasant face, boasting 500 warriors, and called himself "Tonka Capitain," or the great captain.

Besides these there were Cos-o-me-nah, dark, silent, stealthy; Wa-kon-sa, Umpashotah's son, a dude, painting his cheeks, forehead and chin with stars; Mo-koc-aque-mon, Inkpadutah's oldest son, who was shot for his part in the Spirit Lake massacre, with low forehead, scowling face and thick lips; Mo-co-po-co, Inkpadutah's second son, sullen and ill favored.

\section{First Call For Troops}

The company at the fort had supervision of the entire territory from the head of the Cedar river to the Missouri. The first call upon them was in the 
fall of 1851, on the occasion of the robbing of a trapper named Green, who was caught in Sac county and stripped of everything. In 1852, five families living on the Boyer river, sixty miles southwest of the fort, were raided. A young man and young woman and all the horses and property were taken by the Indians, who fled to the north. The troops caught Inkpadutah and Umpashotah at Granger's Point near the Minnesota line and brought them to the fort to be held as hostages until everything was returned. In ten days the young people and property were back, the "good Indians" who were caught telling about the chase they had had after the "bad.,Indians" who had committed the depredations.

The soldiers were ordered to leave the fort in September, 1853. Major Williams, his son James, and John Keffley remained. It was. after the abandonment of the fort that the outrages most intimately associated with our early history were perpetrated. Of these by far the most important in its after effects was the murder of Sidominadotah by Henry Lott at Bloody Run in Humboldt county in January, 1854.

Major Williams, records one fact in connection with the Sioux which is very singular. In all the raids made by them a very large negro was a prominent participant. The soldiers tried often to capture him, but failed. He was one of the boldest and most reckless of the savages in every outrage which was perpetrated during these years.

\section{The Capital Most Needed}

Thought, not money, is the real business capital, and if you know absolutely that what you are doing is right, then you are bound to accomplish it in due season.-Harvey S. Firestone. 
Copyright of Annals of Iowa is the property of State of Iowa, by \& through the State Historical Society of Iowa and its content may not be copied or emailed to multiple sites or posted to a listserv without the copyright holder's express written permission. However, users may print, download, or email articles for individual use. 